Document downloaded from:

http://hdl.handle.net/10251/113846

This paper must be cited as:

Marqués Pérez, I.; Mora Navarro, JG.; Pérez-Salas Sagreras, JL.; Velilla-Torres, JM.; Femenia-Ribera, C. (2018). Agricultural land values using Geographic Information Systems: design location model and tools for information available by geoportal. Application to a Spanish Agricultural Area. Survey Review (Online). 50(363):545-554. doi:10.1080/00396265.2017.1350342

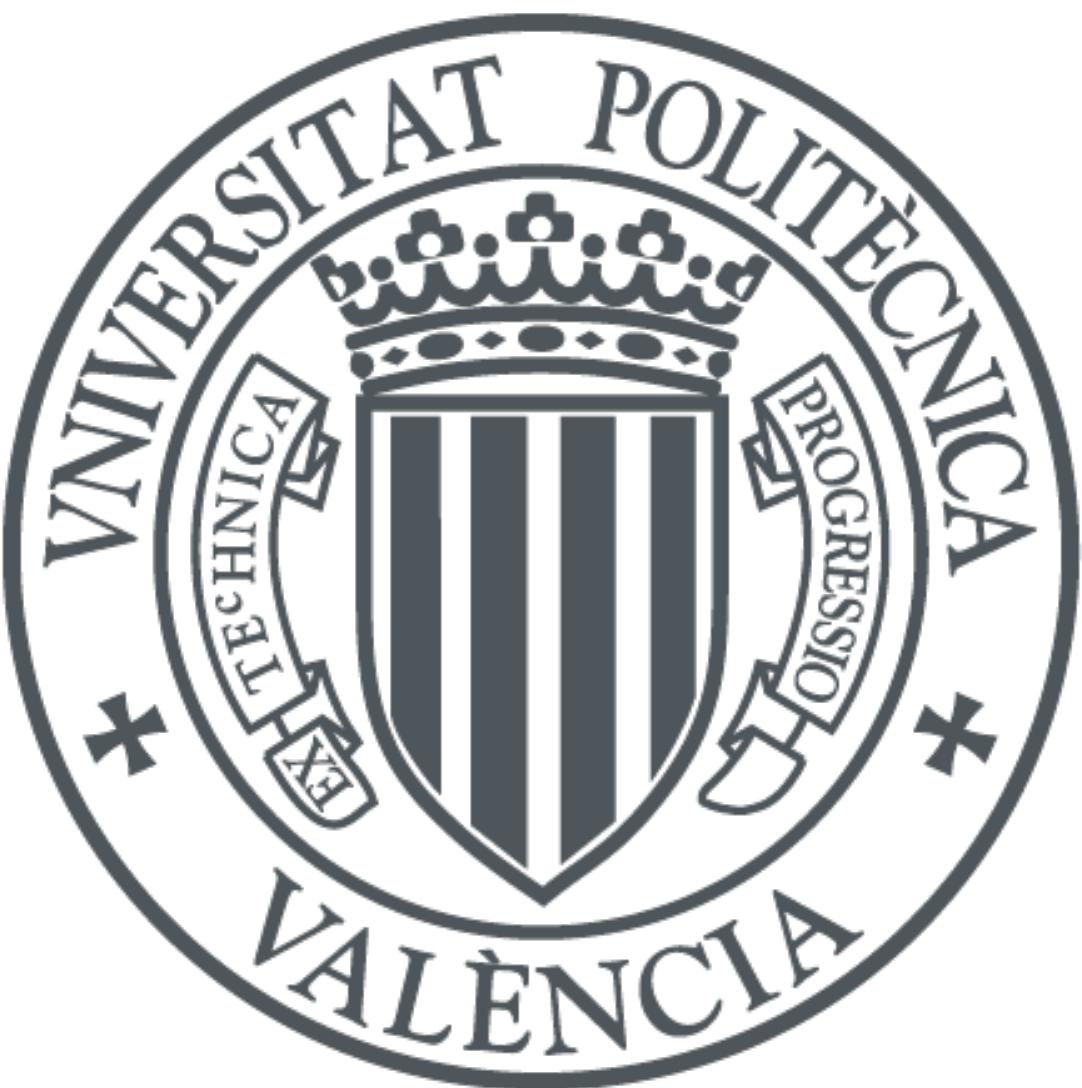

The final publication is available at

http://doi.org/10.1080/00396265.2017.1350342

Copyright Maney Publishing

Additional Information 


\section{Agricultural land values using Geographic Information Systems:}

design location model and tools for information available by geoportal. Application to a Spanish Agricultural AreaType or paste the title of your article here

Inmaculada Marques-Perez

Department of Economic and Social Sciences, Universitat Politècnica de València $(U P V)$

Camino de Vera, s/n, 46021 Valencia, Spain. Tlph: + 349638770 07, ext. 74705

Corresponding author, e-mail address: $\underline{\text { imarques@esp.upv.es }}$

Gaspar Mora-Navarro

Department of Cartographic Engineering, Geodesy and Photogrammetry Department, Universitat Politècnica de València (UPV)

Camino de Vera, s/n, 46021 Valencia, Spain. Tlph: + 349638770 07, ext. 74705

e-mail address: joamona@cgf.upv.es

Jose-Luis Perez-Salas

Department of Economic and Social Sciences, Universitat Politècnica de València $(U P V)$

Camino de Vera, s/n, 46021 Valencia, Spain. Tlph: + 3496387 70 07, ext. 74705

e-mail address: jlperezs@esp.upv.es

Joan Velilla-Torres

Department of Cartographic Engineering, Geodesy and Photogrammetry Department, Universitat Politècnica de València (UPV)

Camino de Vera, s/n, 46021 Valencia, Spain. Tlph: + 349638770 07, ext. 74705 
e-mail address: joavetor@alumni.upv.es

\section{Carmen Femenia-Ribera}

Department of Cartographic Engineering, Geodesy and Photogrammetry Department, Universitat Politècnica de València (UPV)

Camino de Vera, s/n, 46021 Valencia, Spain. Tlph: + 3496387 70 07, ext. 74705

e-mail address: $\underline{\text { cfemenia@cgf.upv.es }}$ 


\title{
Agricultural land values using Geographic Information Systems: design location model and tools for information available by geoportal. Application to a Spanish Agricultural Area.
}

\author{
Quantifying the effect of location on land values can be done by designing a \\ location factor which considers the most relevant aspects that may influence this \\ value; e.g., proximity to large cities, the population living around the parcel or \\ land to be valued, the distance from it to markets or logistic centers, or the \\ existence of places of environmental or landscape interest. Considering these \\ variables can be complicated by having to process large amounts of distinct data \\ (distances, no. of inhabitants or population size, protected areas, etc.), which have \\ to be processed and interpreted to be able to define the factor that summarizes \\ them, and can affect the land value from income, such as productive assets, to \\ correct its value.
}

The main proposal put forward in this research is to study the various location aspects that affect land values, and the possibilities that Geographic Information Systems (GIS) offer to design with free software tools that allow simple calculations of a location correction factor and, consequently, land values. Calculations were made for all the rural cadastral parcels (2.3 million) in the Valencian Region. Results can be integrated into a new online GIS portal and make these available to users in soil valuation studies.

Keywords: agricultural land values; cadastral parcel; geographic information system; geoportal; location model; location factor; postgis; postgres.

\section{Introduction: Previous studies on farmland values and factors that determine their value}

The commonest approach used for determining farmland value is to calculate the land value based on the recorded traded price of the basic farmland. This farmland value is supposed to reflect the sum of the values of individual land features; e.g. land productivity, soil fertility, location of land, and the value of other assets on the land, such as fences, houses, wells, trees and availability of irrigation facilities. Absence of a formal land market, and the tendency to under-report land values by buyers and sellers 
at the time of land transaction recording, are the two inherent problems that lead to undervalue farmland according to this method (Awasthi 2012). Researchers have proposed several alternative land valuation methods (Awasthi 2014). Given its productive asset nature, the first would be the capacity to generate income from agricultural production (Burt 1986) (Featherstone 2003) (Delbecq et al. 2014). Here the value is determined by means of the discounted future cash flow from the farm. However, this land value can also be explained using other sources of income; e.g. existence of a compensatory agricultural payments policy system, regardless of it being of prices or leases (Mishra and Goodwin 1996) (Goodwin et al. 2003) (Featherstone 2003) (Ahearn and El-Osta 2006), or the potential development of urban land use activities (Plantinga and Miller 2001) (Livanisi et al. 2006) (Cloquell Ballester et al. 2007). Moreover, the value for the capacity to supply environmental and recreational services is increasingly being acknowledged (Polaski et al. 2014) (Plantinga et al. 2014). Other authors have even pointed out that hunting leases exist to increase rural land values (Hussain et al. 2013). All these considerations explain, to a certain extent, the fact that rural land values, and variations to them, do not correspond in most cases to agricultural use, income from agricultural production and any variations to them.

It is important for landowners, land demanders and land policy analysts to recognise what factors drive land prices. Making land valuations, from a private perspective, for buying and selling transactions, for estimating business assets values of holdings, from owners' individual assets to constitute mortgage burdens, etc., or from the public administration perspective when defining taxes and duties, or establishing compensations during expropriation processes carried out as part of infrastructure projects, or during expropriation processes that involve public assets, etc., involves having to consider many variables. 
Agricultural variables, such a parcel size, agricultural features (land type, orography of land, climate, etc.), condition crop yields and, consequently, income. It can be stated that these variables are taken into account when calculating the income that can be made from holdings. Then they will be deducted to calculate land values. Compensatory payments are directly added to the land value in accordance with the system set for them, provided this agrees with the declared incomes obtained from holdings, and are used to calculate the land value or to pay for land cover.

In valuations however, considering the spatial distribution of activities, and the potential undertaking of them, in relation to the location of the land and the characteristics of its surroundings means having to bear in mind certain aspects like the existence of own centres, and their size, if there are logistics centres near, presence of areas of high environmental and/or landscape value, if public planning instruments exist which can condition land use, etc. All these aspects can make calculating values complicated as many data of different types must be processed (distances, no. of inhabitants or population, protected areas of different kinds, etc.), which have to be processed and interpreted. So it is interesting to define a factor that summarizes these data and which can affect the land value from income as productive assets to correct its value, and to consider these location-related variables. This factor we call location factor.

Geographic Information System (GIS) allows us to separate information into various layers of themes and to store them independently to work with this information rapidly and easily, and to facilitate the possibility of relating existing information through the topology of objects in order to generate other information which we would not obtain in another way. What distinguishes GIS the most from other systems used for drawing, processing images, designing maps, digital atlases, etc., is the operations and 
analysis algorithms it permits by using the data contained in different layers. It is an important tool to process relevant land location variables and to simply generate the location factor values that correct calculated land values using income.

In Spain, the amendments made to land laws have introduced novel aspects to consider rural land locations, including a location correction factor that contemplates these variables: distances from the land being valued to city centre, size of city centre (no. inhabitants or population), proximity to protected areas of different kinds (environmental or landscape), etc.

Web information technology, enables the development of communication into online GIS portals. Geoportal was defined by Resch and Zimmer (2013) as a web-based system that allows users to discover particular geo-datasets by looking into the associated metadata, to portray the data on a map, and to retrieve the data in adequate formats to further process them in a professional workflow. So, it can be an important reference tool in order to help achieve more transparent and efficient agricultural land market. This paper develops a new geoportal with the research results.

For all these reasons, we put forward some working hypotheses to be used in our research

- 1 st Given the nature of the productive asset, the rural or agricultural land value is set by its capacity to generate income from agricultural production.

- 2nd It is generally accepted that factors linked to a socio-economic setting must also be considered relevant for land values. We must pay special attention to the effect of the spatial distribution of economic activity as this is conditioned by many different types of variables.

- 3rd Land value calculations can be complicated to a great extent by location, by the need to process a vast amount of data of distinct types (distances, no. of 
inhabitants or population, protected areas of different kinds, etc.), which have to be processed and interpreted.

- 4th GIS tools allow relevant location variables that can influence the land values to be considered and processed.

- 5th Web information technology enables the development of communication into online GIS portals.

The objectives of this research work are: to investigate new tools to study the value and spatial distribution of land, particularly rural land, by studying the aspects that have a direct influence on its price; to demonstrate the power and versatility of the GIS, PostgreSQL + PostGis (PostGIS) tools in making calculations with the spatial relations among objects; to propose the design of a GIS tool or application that calculates the location correction factor contemplated in Spanish legislation by means of the algorithms implemented into the PL/PGSQL functions. The designed tool was applied to calculate the factor for all the rural cadastral parcels in the Valencian Community. If the results are integrated into an online GIS portal available to users, it is possible achieve more transparent and efficient agricultural land market.

\section{Land value according to location: location models of economic activities}

Although some authors have considered that the price of real estate assets depends exclusively on their intrinsic characteristics, such as Ricardo's explanation on land leases, it is generally accepted that the factors linked to the socio-economic setting must also be considered relevant. Indeed we must pay special attention to the spatial distribution of economic activity (Cervelló Royo, 2008).

The location problem of economic activities has evolved from a descriptive approach ever since it came about in the 18th century, to then move on to an 
explanatory-predictive-speculative approach, which is typical of economic doctrine, to be finally defined as a decision problem that depends on many criteria (Cloquell Ballester et al. 2007).

The effect of urbanization and development on land values is closely related with the spatial distribution of economic activity. Since the end of the 20th century, many economists have voiced concern about economic effects deriving from an area, and studying the location problems of economic activities in accordance with certain aspects, such as transport costs depending on location, location of existing markets and the distribution of factors. In this initial phase, and given the importance of the agricultural sector as it was the main sector of activity at the beginning of the 20th century and earlier, many contributions have been made to this aspect, of which the following stand out (Von Thünen 1826, Weber 1909, Christaller 1933, Lösch 1940, Alonso 1964 and Beckman 1958, 1986) ${ }^{1}$.

Back in 1826, Von Thünen (Von Thünen, 1826) analyzed how crops were arranged around town markets. He tried to demonstrate that farmers grew less intensely the further away they were from town markets since transport costs increased, and also as a way to cut holdings' costs to offer more competitive sale prices. And so it was that crops had to be arranged in concentric circular zones around a city according to a gradient of yields. Better yielding crops were grown on the holdings that were closer, which consequently led to better economic outcome.

In 1909, Weber was interested in geometrising the spatial distribution of economic activity. The best location for each activity was that which would minimize the costs related to transferring inputs and outputs, provided the existence of economies

\footnotetext{
${ }^{1}$ In (Ramón, 1976)( (Hormigo, 2006) (Faíña et al. 2006)
} 
of agglomeration was taken into account. Then the relevance of the proximity of a given activity to not only the business centres of cities, but also to logistic centres that could guarantee access to outputs, was introduced. Similarly Christaller in 1933 and Lösch in 1940, who both reviewed Von Thünen's model, established compensation between economies of scale and transport costs to define a framework of "central places", where each one would be in charge of supplying farmers in their surrounding area. Thus assets and services were distributed from each city to those of a lower level and located in their area of influence. So the consideration of not only proximity to town centres, but also their size, was introduced.

Rosen and Freeman independently developed theoretical models for differentiated consumer products in 1974 (Freeman, 1974) (Rosen, 1974). This was the basis to empirically estimate marginal prices of characteristic products. Palmquist (1989) extended Rosen's theoretical model to consider land to be a differentiated production factor and to make land value estimations, and the characteristics that it depends on. The theoretical framework of this analytical methodology is fixing hedonic prices, based on the hypothesis that characteristics of non-homogeneous assets, like land, are valued as a function of their usefulness attributes. Many authors have used this methodology to estimate land values. The advantage that this method offers is that it is possible to deal with many factors according to the many existing theories on land values. Therefore, most of these studies can be grouped into two categories: one group of studies that estimates land values according to edaphic characteristics $(\mathrm{pH}$, erosionability, soil depth, etc.); another group that explains land values by the effect of urbanisation and development (Roka and Palmquist, 1997).

Following these theories, in the studies that valued land many authors included attributes or characteristics such as: measurements of the distance from parcels to roads 
or infrastructures and to town centres (Hushak and Sadr 1979) (Chicoine 1981), (Vitaliano and Hill, 1994) (Elad et al. 1994) (Colwell and Munneke 1997) (Shi et al. 1997), population counts, population density and any variations in them (Palmquist and Danielson 1989) (Elad et al. 1994) (Plantinga et al. 2002) (Huang et al. 2006) as proxy variables. Yet in these works, the authors have shown that they were unable to separate any contributions made to land market values, incomes due to agricultural use and incomes due to potential development.

One solution proposed in Spain by Caballer (2012) to modify land law introduced novel aspects in relation to the rural land location consideration, which included a location correction factor. According to this proposal, the final land valuation should bear in mind the specific spatial location of real estate, and apply a global correction factor to the land value obtained by capitalizing returns, if applicable. Caballer's proposal requires using a large amount of data for the different variables (distances, no. inhabitants/population, protected areas of different kinds, etc.), which must be processed and interpreted. These data are found in public databases: General Directorate for Cadastre (DGC); Spanish National Statistics Institute (INE); Valencian Regional Statistics Institute (IVE); Biodiversity Bank, etc. Lots of them are already available in the usual digital GIS forms.

\section{Free GIS tools to determine land values}

In this research, we exclusively used the free software (FOSS) for data processing and calculations since the free tools there are available are powerful enough for the pursued objectives. We used the following:

- $\quad$ PostgreSQL for data processing and storage

- $\quad$ PostGIS for adding a support for the geographical data to PostgreSQL 
- $\quad$ QGIS as a GIS desktop program for consulting and viewing data

- $\quad \mathrm{PL} / \mathrm{pgSQL}$ for programming the spatial calculation functions in PostgreSQL

Free software is becoming increasingly advanced and competitive. This comes over clearly in the work by Sarrab and Rehman (2014), who studied eight known free software programs after dividing them into two main themes, networks software and network learning software, and applying a quality model to their characteristics. Bouras et al. (2014) presented a series of considerations and recommendations for public administrations that suggest selecting free software to process their data. Their work indicates that given its characteristics, free software is suitable for sharing data between the different parts that make up the public administration. Among its characteristics, using open standards is highlighted as they allow data to be shared among the various parts of the administration. Other software used for GIS studies are explained in B. Idrizi et al. (2014).

PostGIS is an extension that converts the PostgreSQL database into a spatial database. PostGIS can be used to store spatial data. It also allows new personalised spatial functions to be created which, in turn, permit calculations by combining the native PostGIS functions to be applied on several spatial layers. The combination of both is the perfect solution for storing, processing and maintaining spatial data. This allows real-time topological verifications to be made in the database. In this way, the work done to maintain the topological consistency of spatial objects is carried out in the database, which offers great advantages (Van Oosterom et al. 2002) as in M. Zymunt (2014). When these verifications are made in real time in the database, a dynamic data model is obtained, like that developed by Mora-Navarro (Mora-Navarro 2013). The new 
functions scheduled in the database can also automate those calculations that consider areas, distances, intersections, etc., as in the present work.

With PostgreSQL + PostGIS, we implemented the PL/PgSQL function into a database which contained its respective algorithms to solve the calculation of the location correction factor. This function has no limited use because the tables with the necessary results are eliminated and are created again upon each use. This calculation function employs cadastral cartography to evaluate and obtain 12 tables with coefficients (correction factors), calculation parameters and the location factor. In any case, the determining factor in the implementation and the location factor calculation is cartography, which is the information required to be added to a database in order to do spatial calculations. As a practical application, the calculations of the location correction factor were done for all the rural cadastral parcels throughout the Valencian Community. For this purpose, the documents offered by the Electronic Cadastre Office (SEC) of the General Directorate for Cadastre were used; the downloading centre of the Spanish National Centre of Geographical Information (CNIG), which corresponds to the Spanish National Geographical Institute (IGN); the Spatial Data Infrastructure of the Valencian Community: Terrasit; the Natura 2000 Network of the Spanish Ministry of Agriculture, Food and the Natural Environment (MAGRAMA).

\section{1.- Case study: model correction factor}

As mentioned earlier, the Spanish regulation on Land Law 2/2008 proposes that the final land valuation should bear in mind the specific spatial location of the real estate and apply, if applicable, a global correct factor to the capitalisation value with this expression:

$$
\mathrm{Vf}=\mathrm{V} * \mathrm{FL}
$$


where:

$\mathrm{Vf}=$ Final land value in euros

$\mathrm{V}=$ The capitalization value of income from the holding in euros

$\mathrm{Fl}=$ Global location factor

The global location factor, result by multiplying the following three correction factors:

$$
F l=u_{1} * u_{2} * u_{3}
$$

(1) For accessibility to town centres, $\mathrm{u} 1$.

(2) For accessibility to centres of economic activity, $u 2$.

(3) For locations in settings of singular environmental or landscape value, u3.

\subsection{Calculating correction factor $u 1$}

The correction factor $\mathrm{u} 1$ is calculated by the following expression:

$$
u_{1}=1+\left[P_{1}+\frac{P_{2}}{3}\right] * \frac{1}{1.000 .000}
$$

$\mathrm{P} 1=$ The number of inhabitants in population centres located at a distance of less than 4 $\mathrm{km}$, as the crow flies, understood as the distance in a straight line measured over the projection on a horizontal plane

$\mathrm{P} 2=$ The number of inhabitants in population centres located at a distance of more than $4 \mathrm{~km}$ and less than $40 \mathrm{~km}$, understood as the distance as the crow flies, or as a 50minute trip on usual means of transport under normal conditions (Fig. 1)

To calculate the first correction coefficient that considers accessibility to population centres, some algorithms that calculate $\mathrm{P} 1$ and $\mathrm{P} 2$ are implemented. These algorithms create and store in tables the summations of population centres that meet the distance conditions in relation to the spatial object, a rural parcel in this case. This 
process allows the calculation of their respective $\mathrm{P} 1$ and $\mathrm{P} 2$ parameters using a cadastral cartography level, and a posteriori with the above formula, it allows the first correction factor for all the rural parcels.

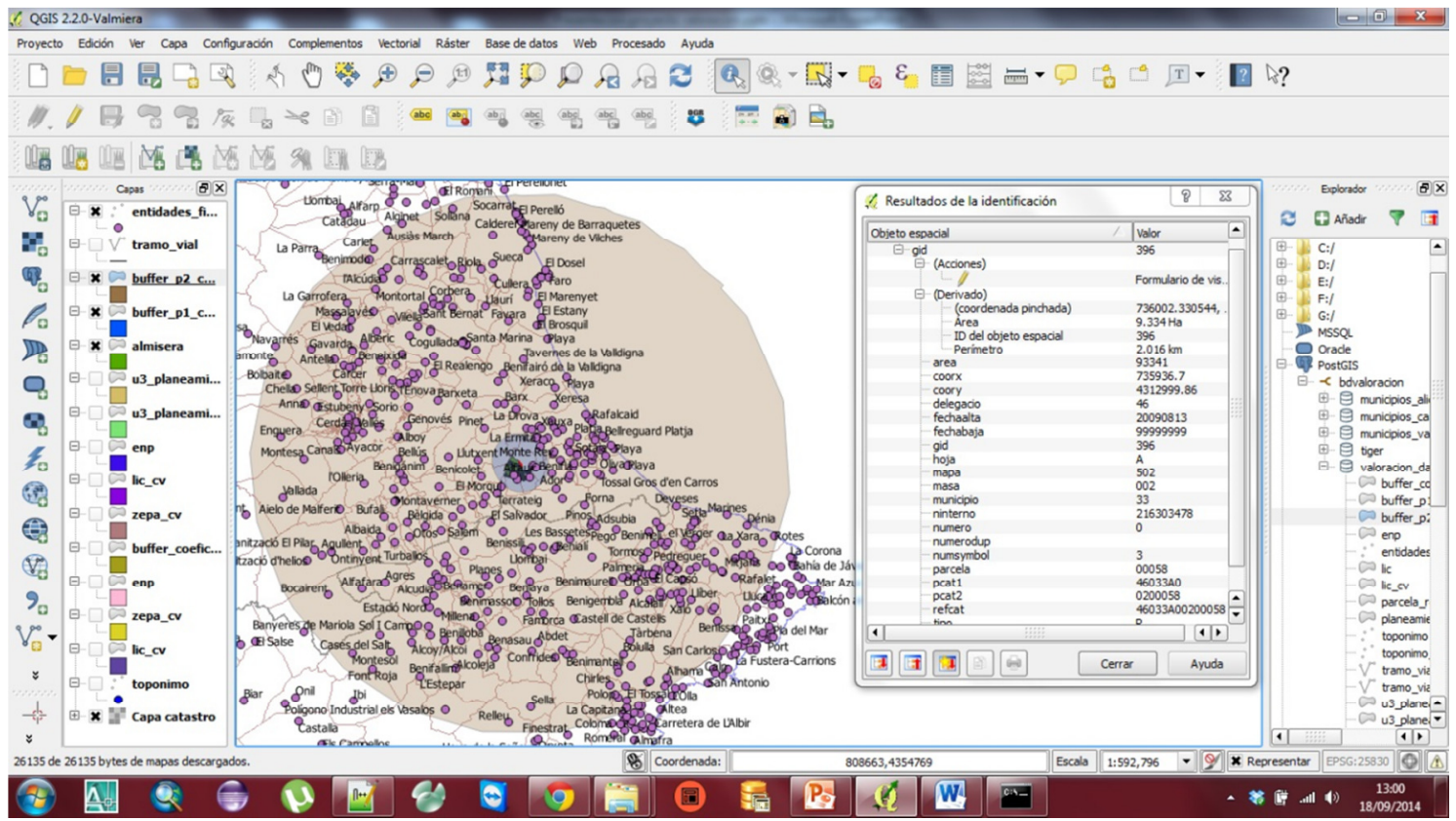

Fig 1. Calculating the $\mathrm{P} 2$ parameter (a $40 \mathrm{~km}$ radius)

\subsection{Calculating correction factor $u 2$}

When any rural land to be valued is close to communications and transport centres, given their proximity to sea ports, airports, railway stations and intermodal areas, and their proximity to large city complexes of tertiary, commercial or productive use related to the activity undertaken by the holding that is to be evaluated, correction factor $\mathrm{u} 2$ is calculated by the following expression:

$$
u_{2}=1,6-0,01 d
$$

$\mathrm{d}=$ Distance in kilometres from the real estate that is the object of the valuation using existing transport routes and considering the most favourable route. Under no 
circumstances should this distance be more than $60 \mathrm{~km}$. (Fig. 2).

The second correction coefficient considers accessibility to centres of economic activity: proximity to communications and transport centres, close location to sea ports, airports, railway stations and intermodal areas, and their proximity to large city complexes of tertiary, commercial or productive use related to the activity undertaken by the holding that is to be evaluated.

For this calculation, the algorithms that consider centres of economic activity and communication channels at a distance of $10 \mathrm{~km}$ at the most from the spatial object to value are implemented. Only those that are of a minimum distance are taken into account; that is, only the nearest ones to the object to be valued within their set of centres of economic activity and communication channels. The mean of these minimum distances is created and stored in a table, which corresponds to this distance, along with the previously named parameter $\mathrm{d}$. This procedure allows the calculation of its respective parameter $d$ with the cadastral cartography layer, and a posteriori, the second correction factor for all the rural parcels with the previous formula used.

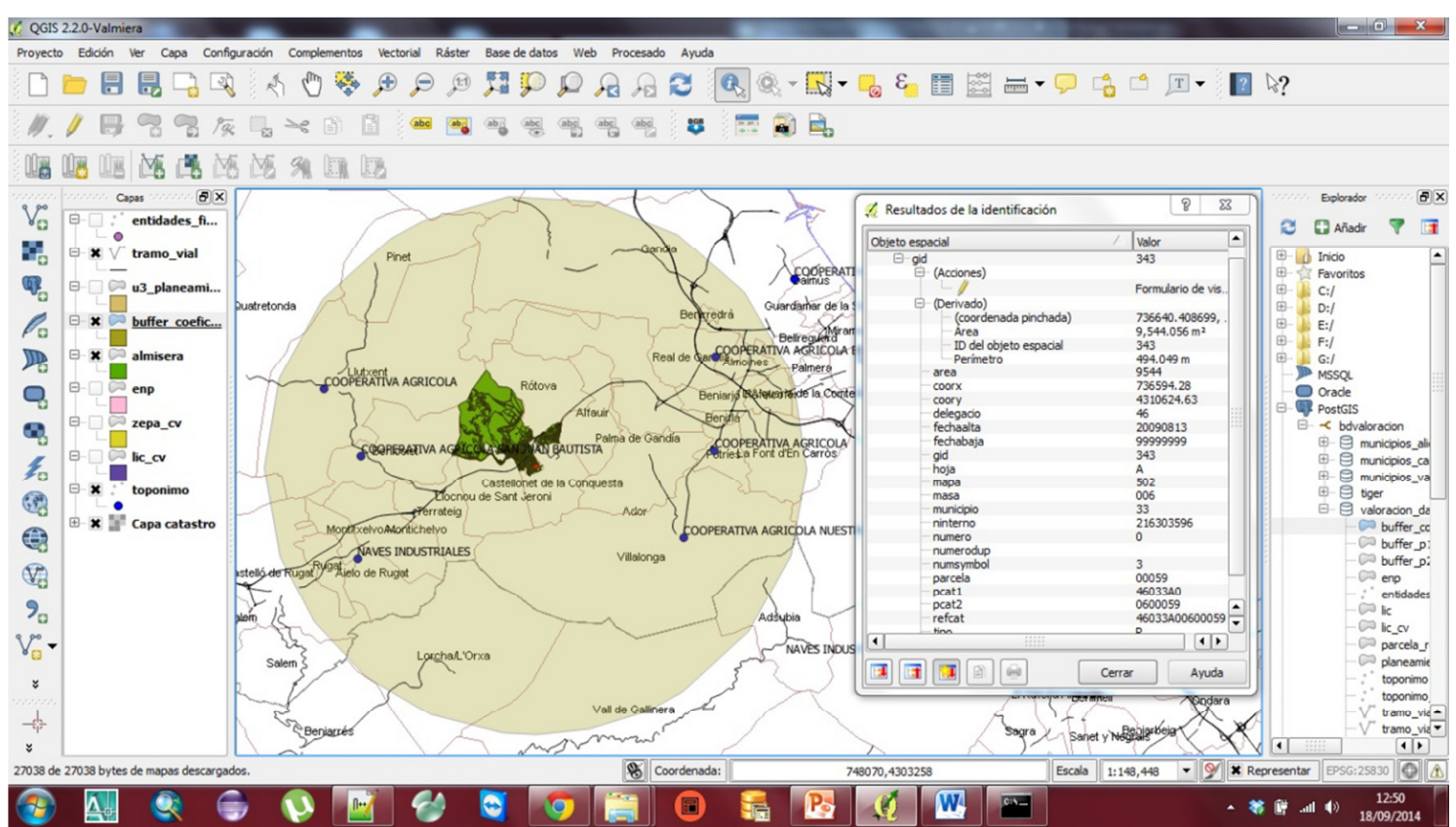

Fig. 2. Calculating "d" parameter 


\subsection{Calculating correction factor u3}

When the rural land to be valued is located in places with singular environmental or landscape value, correction factor $\mathrm{u} 3$ is applied, which is calculated according to this expression:

$$
u_{3}=1,1+0,1(p+t)
$$

$p=$ weighting coefficient according to environmental or landscape quality

$\mathrm{t}=$ weighting coefficient according to the system of uses and activities

When it comes to applying correction factor $\mathrm{u} 3$, we consider places of singular environmental or landscape value those protected by applicable legislation, or those included in the Natura 2000 Network, because of their environmental, cultural, historic, archaeological, scientific and landscape value.

Weighting coefficient $\mathrm{p}$ should be determined on the objective criteria basis in accordance with the recognized values of the lands being valued in town planning and territorial instruments, or in networks of protected spaces. This coefficient takes values between 0 and 2, and considers the values and qualities of the surroundings. It is higher the better the environmental and landscape quality is, or the higher the cultural, historic, archaeological and scientific values are.

Solving the third correction factor is done using algorithms which, this time, contemplate the spatial position of the parcel to be valued with its intersection with some of the aforementioned layers. A table is made for each layer to be intersected, which contains the attributes of both the parcel and the intersected entity in the same register. To the attributes of the intersected entity, a value is added, which is obtained 
from the influence these attributes have on the valuation. With coefficient $p$, if any of the Protected Natural Areas (PNA), Sites of Community Importance (SCI) or Areas of Special Protection of Birds (ASPB) layers intersect with the parcel, a maximum value of 2 is added to it. Coefficient $t$ takes a value of 7 if the intersection entity corresponds to a quarry or to wind power plans or areas, a value of 1 if it corresponds to a landscape, forest, ecological or archaeological area, and a value of 0 for all the other cases. This procedure allows a calculation to be made with the cadastral cartography layer of the corresponding parameters $\mathrm{p}$ and $\mathrm{t}$ and, a posteriori, with the third correction factor for all the rural parcels using the previous formula.

Weighting coefficient $t$ is applied only when it is accredited that, according to town planning and territorial instruments, allows a system on lands of uses and activities that differ from agriculture and fishing or forest uses and activities, which increase its value. This value lies between 0 and 7 , and it deals with the influence of a given system of uses and activities on an increase in the land value without considering any urban expectations, and is higher the greater this influence is. This coefficient is related with the planning and arrangement layer of the land.

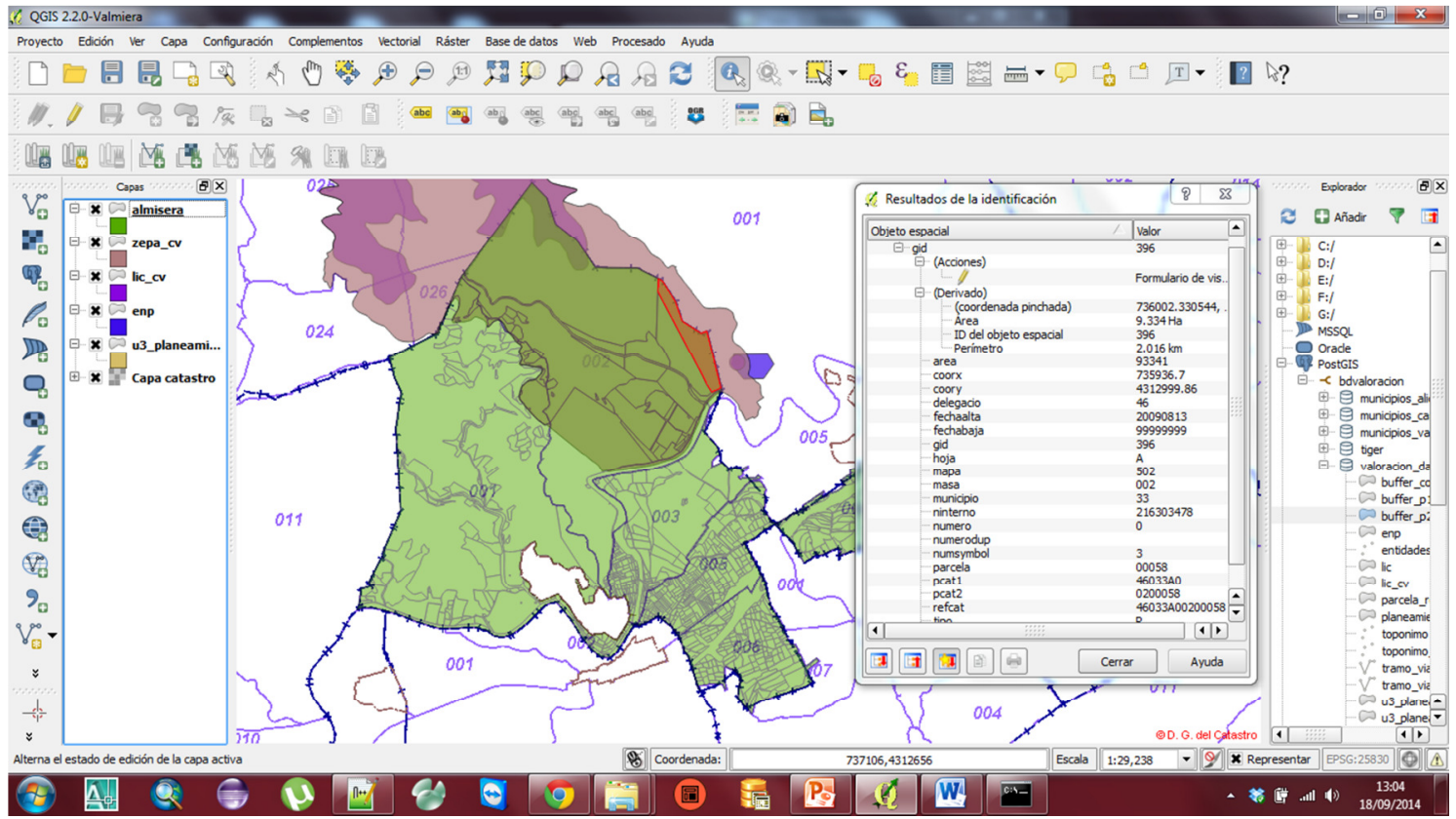


Fig. 3. Calculating " $t$ " and "p" parameter

With the three correction factors obtained, the calculation made of the location correction factor is solved by the multiplication of all three (2).

\section{5.- Geoportal developed to calculate online the location factor}

In recent years the open source web development community has enabled drastic improvements in the functionality, design, and user experience of these sites (Ganning, Coffin, McCall, \& Carson, 2014). In our research we used Mapserver (http://mapserver.org), to publish the WMS service (http://www.opengeospatial.org/standards/wms) of the cartographic layers, Python (https://www.python.org), as software language to recipe the HTTP application, for data input, and HTML response page. We also use OpenLayers (http://openlayers.org), as thin-client for displaying our WMS service maps. By using these tools, it was designed a geoportal to offer static maps with the parameters necessary to calculate of location factor value. Membership is open to the public, with an approval process for becoming a "data provider," to those users who want take data sets about location factor value and land value.

Membership can use the interactive mapping and GIS site designed, without specific software. To visit this geoportal they only need have an internet browser installed on your computer. So, the maps information, location factor value and land value can be available for more people. Through the geoportal, everybody who want know value of a cadastral parcel in Comunidad Valenciana, can test the location factor, and every parameter, coefficient and variables. Geoportal is available in: http://upvusig.car.upv.es/valoracion/index.cgi. All cadastral parcel in Spain, have a 
reference in the national cadastral register for your identification. We take a reference in geoportal or choose a parcel in the map to calculate the location factor value.

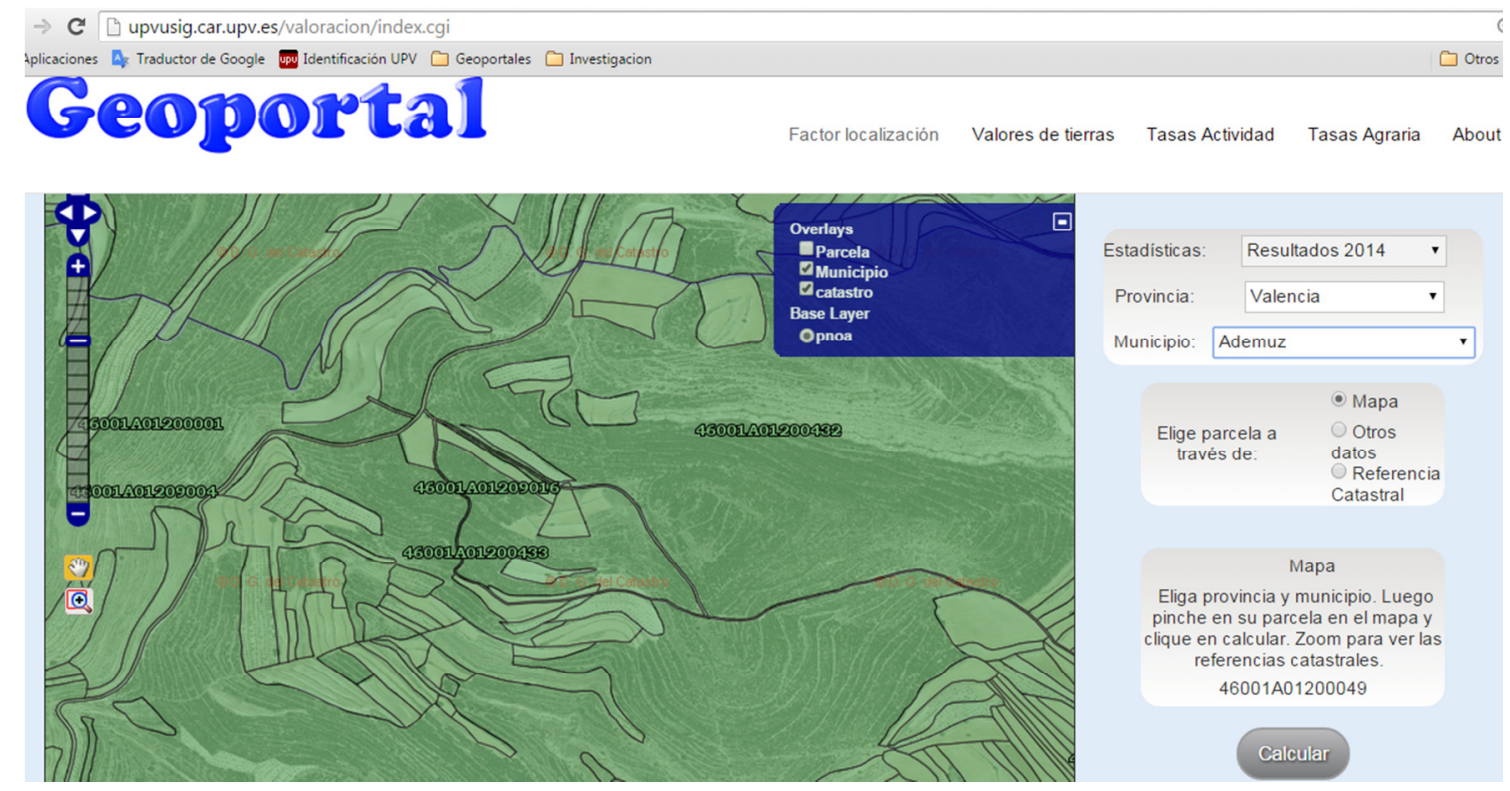

Fig. 2. Geoportal interface for the calculation of the location factor

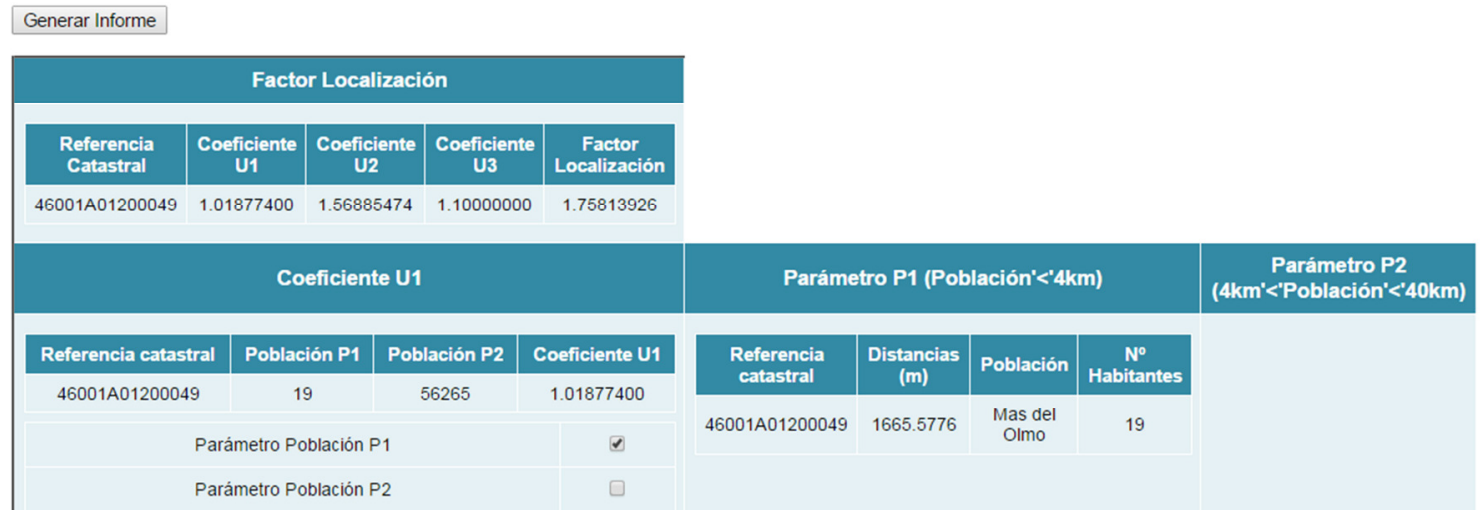

Fig. 3. Report result of a location factor of a plot

Geoportal generates a report in pdf format with the location factor value and all the parameters for the calculation of the location factor.

\section{Results of calculating the location factor in the province of Valencia}

The cartography, or set of the territorial documents of our specific study area, was downloaded from different public web sites as shapefiles to be a posteriori imported to 
the Postgres database. All the layers required are:

(1) Cadastral parcels $\rightarrow$ SEC-DGC

(2) Town centres $\rightarrow$ IGN

(3) Toponymy and Essential Stretches $\rightarrow$ IGN

(4) Consideration $\rightarrow$ Terrasit

(5) $\quad$ Natura $2000 \rightarrow$ MAGRAMA

Then the PL/PgSQL function finishes, which is done for all the municipalities in the Valencian Community, of which there are 533.

Deliverables come as Access databases. So every time a function is calculated and finished for a municipality, all the tables required in Postgres are imported to a new Access database, with one table for each municipality (533 in all).

For this purpose, a Backup and Restore are done of the databases in Postgres. It is necessary to install all the software in seven computers to speed up the work and to cut times. The end results occupy about 115 Gigas in the databases with more than 2 million valued rural cadastral parcels.

Using the developed functions, all the location factors are automatically calculated for all the parcels in all the municipalities in the Valencian Community, which comes to 533 municipalities, 2,299,140 parcels and 164 natural and/or protected areas (Table 1). With these values, we calculated the maximum, minimum and average values, and the coefficient of variation $(\mathrm{CV})$ of coefficients $\mathrm{U} 1, \mathrm{U} 2, \mathrm{U} 3$ and FL of all the municipalities in the Valencian Community. We verified whether the CV value explained greater heterogeneity of the FL values in a municipality or, otherwise greater homogeneity. Therefore, we could use the mean FL values calculated for each municipality to calculate the value of any of the parcels in a given municipality, which considerably simplifies the FL calculation. 
Table 1. FL and CV values for all three provinces in the Valencian Community

\begin{tabular}{|l|l|l|l|}
\hline & Alicante & Castellón & Valencia \\
\hline No. of municipalities & 139 & 135 & 259 \\
\hline No. of rural parcels & 475.720 & 684.305 & 1.139 .115 \\
\hline Natural/Protected Areas & 58 & 46 & 60 \\
\hline Minimum FL (Maximum FLs) & 2,1597 & 1,7755 & 1,7625 \\
\hline Minimum FL (Average FLs) & 2,0402 & 1,7651 & 1,7414 \\
\hline Minimum FL (Minimum FLs) & 1,9007 & 1,7381 & 1,6873 \\
\hline Minimum CV (CV of FLs) & $0,11 \%$ & $0,11 \%$ & $0,11 \%$ \\
\hline Maximum FL (Maximum FLs) & 4,4457 & 3,5185 & 5,3245 \\
\hline ML Maximum (Average FLs) & 2,9848 & 3,2226 & 3,6837 \\
\hline FL Maximum (Minimum FLs) & 2,8761 & 2,8436 & 3,3681 \\
\hline Maximum CV (CV of FLs) & $11,89 \%$ & $12,59 \%$ & $21,20 \%$ \\
\hline Mean FL (Maximum FLs) & 2,9230 & 2,4487 & 2,9724 \\
\hline & 2,4662 & 2,1669 & 2,5289 \\
\hline & 2,3274 & 2,0032 & 2,3694 \\
\hline & & & \\
\hline
\end{tabular}

From these results, we can deduce that the municipality of Llombai (province of Valencia) obtained the maximum FL of the whole Valencian Community, with a value of 5.3245. The municipality of Llombai is located $29 \mathrm{~km}$ from the city of Valencia. Its 
population density is 50 inhab./km2, its municipal surface area covers $55.57 \mathrm{~km} 2$, there are 8,121 rural parcels and one SCI (a cave known as Cova de Les Meravelles de Llombai). Its minimum and average FL are 2.8946 and 3.0422, respectively, with a CV of $7.34 \%$ (Table 1$)$.

The minimum FL of the whole Valencian Community goes to the municipality of Aras de los Olmos (province of Valencia), with a value of 1,6873, which is located $98 \mathrm{~km}$ from the capital of Valencia. Its population density is 6 inhab./km2, its municipal surface covers $76.04 \mathrm{~km} 2$, and it has 8,611 rural parcels and no protected or natural area. It obtained a maximum FL of 3.1843 and an average FL of 2.0109. Its CV, the highest for the whole Valencian Community, was $21.20 \%$.

\section{Conclusions}

The literature on land values has consistently shown that farmland prices near urban and developed areas are higher (e.g., (Huang et al. 2006); (Livanisi et al. 2006); (Plantinga et al. 2002)). We can identify some reasons: firstly, many cities were initially established near particularly fertile soils (Barnard, 2000); secondly, farmland near urban areas is also typically devoted to produce high value commodities (Livanis et al. 2006); thirdly, location in relation to markets. These effects are assumed to be captured through rental rates. However, agricultural land provides land for current and future developments, recreation, access to public lands, wildlife habitats and open spaces. So land values are only partially explained by agricultural income. Many non-agricultural attributes of farmland also contribute to the market value (Borchers et al. 2014). Some research papers on land values have used the hedonic model to estimate attributes or explanatory variables of value. Huang et al. (2006) conclude in their research into the factors that influence Illinois land values that these values drop with plot size, ruralness, distance to Chicago and other large cities, and swine farm density, and they increase 
with soil productivity, population density and personal income. Delbecq et al. (2014) suggest in their research on Agricultural Land Values in the Urban Fringe in Illinois that the impact of population growth is significant and positive within the urban fringe and is non-significant in rural areas. The results of a study conducted in the Rocky Mountain region indicate that remote agricultural lands, which include wildlife habitats, angling opportunities and scenic views, command higher prices per acre than those which primarily have agricultural production capacity (Bastian et al. 2002). Likewise, the research results obtained by Ma and Swinton (2011) in southwest Michigan suggest that ecosystem services are largely capitalised through lakes, rivers, wetlands, forests and conservation lands. In accordance with the conceptual model used, ecosystem services that support direct use values, such as recreational and aesthetic services, are likely to be perceived by land owners and, thus, in land prices. It can be concluded that when productive incomes are estimated that to the land value, by summing the discounted productive incomes, the non-agricultural portion of the value, from land as space for amenities, development and the expansion of urban land use activities, must be added.

In our study we used a location factor, which has been included in a recent review of Spanish Land Law. This location factor employs the aforementioned variables, which have been stressed by some authors as population density, distance to town centres, characteristics of land uses and possible land developments, and the possibility of undertaking recreational activities, by considering the correlations between the value of these variables and the land value, as we saw in the results of this research. The location factor is used to correct the calculated land value by deducting estimated future agricultural incomes, and thus calculating a value that comes closer to the real market value. A topic for future research: how we can take these nonagricultural variables into account. 
In any case, considering non-agricultural variables means having to process a very large amount of data of different kinds (distances, no. inhabitants or population, protected areas of different kinds, etc.), which have to be especially processed and interpreted for each parcel or land division to be valued. GIS methods are complementary procedures capable of enhancing and extending research expertise in rural land markets. They have been used by some authors. Kennedy et al. (1996) provided a hedonic rural land study using GIS. Their analysis identified rural land markets in Louisiana based on economic, topographic and spatial variables. GIS was used to define distance to market as well as soil type variables. Geoghegan et al. (1997) obtained GIS data for two landscape indices and incorporated them into a hedonic model for suburban properties in Washington DC. In Vandeveer et al. (1998), GIS procedures were used to review and estimate the spatial characteristics of a rural land sales database. Geographically referenced rural land sales data were parcelled, and overlapped other data used to compute new data and to obtain rural land value contours. Bastian, et al. (2002) proposed using estimated variables derived from GIS measures, the values of which are uniquely specific to individual land parcels. GIS variables provide a means to quantify amenity attributes, as well as the opportunity to include them in a hedonic price model. The results suggested improved hedonic price model specification for agricultural lands, particularly for the Rocky Mountain and Great Basin regions.

The proposal made in this work was to verify the usefulness of GIS to design, with free software, tools that simply allow calculations of a location correction factor, and with this, land values. The location factor set out in Spanish legislation, as provided in detail in previous sections, considers the following variables: population density, distance to town centres differentiated by sizes, specification of foreseen land uses, 
existence of lands of high environmental value that favour the supply of environmental assets and services, etc. Moreover, these variables have been indicated to condition land prices in many works. Calculations were made for all the rural cadastral parcels in the Valencian Community (east Spain), of which there are some 2.3 million (Velilla et al. 2016).

It has developed a geoportal to put the factor calculation tool in simple and immediately available to users. This generates a detailed report to incorporate it in the assessment of land value. This overview is presented to help planning agencies, universities, regional governments, and municipalities in the conceptual framing of similar, new sites. These result in more transparent and efficient agricultural land market.

The best contribution of this research was the development of the base tool for data collection and its spatial analysis. With this base tool has been made a practical application based on the factor defined by Law 2/2008. For that we have been interpreted some of the parameters considered in definition thereof.

This base tool has been used for the calculation of the location factor for each of the land parcels of the Valencian Community. Also, we offer through a web site the possibility of anyone could calculate and could interpret this location factor. The web site created seek to be a unique framework as diffusion point but also as site to enriching interaction between stakeholders, exchange and gathering of information concerning the land market.

The essential criterion for considering valid results obtained in any research work is the degree to which we can rely on the concepts, methods and inferences of the previous study. In our research, as was designed the proposed location factor. Also in 
the fact that the scientific community and users consider the results as reliable enough to base their work on them.

Firts, the localization factor was designed following the rotational models based on the model proposed by Von Thünen. This model was key to solving a big problem in the early eighteenth century, how to balance the cost of land with the best crop to produce. Von Thünen analysed rational land-use decisions from farmers, and concluded these decisions were based on the land's physical characteristics and its position relative to market centres. His significant contribution was that he was able to identify and explain the spatial elements that help decide how to use the land. In the time since von Thünen, changes in communications and transportation technologies and progress in food preservation methods, such as refrigeration, have changed the significance of some of his theory's variables. However, the basic concepts of the von Thünen model are still valid.

On the other hand, the opening of the Geoportal-UPV, and the results of the consultations carried out by technicians and users, and by the public administration itself, allow us an enriching interaction from which to draw conclusions regarding utility and quality of the values obtained for location factor. Portal users should make an assessment about the quality of the information obtained and its usefulness. Quality refers to reliability, veracity, plausibility, credibility, congruence, etc. related with the correction factor that is calculated and the value of the soil that finally is obtained, and that must be interpreted as market value.

To do the assessment, the users should establish on a scale of 1 to 5 (Likert scale) usefulness of the tool, and quality of data obtained. From the opening, in November 2016, the Geoportal (web-site) has received 1,113 visits, in which users have performed calculations for 667 plots of the CV. And the results valuation is attached 
here. It can be seen users consider the correction value obtained to be completely reliable, uniquely specific to individual land parcels, in order to obtain a single value as a factor that covers all the variables and to calculate the total farmland value.

\begin{tabular}{|c|c|}
\hline \multicolumn{2}{|c|}{ GEOPORTAL VISITS } \\
\hline FECHA & Visits for month \\
\hline $2016-11$ & 87 \\
\hline $2016-12$ & 43 \\
\hline $2017-01$ & 128 \\
\hline $2017-02$ & 79 \\
\hline $2017-03$ & 218 \\
\hline $2017-04$ & 144 \\
\hline $2017-05$ & 328 \\
\hline $2017-06$ & 86 \\
\hline TOTAL & 1113 \\
\hline
\end{tabular}

\begin{tabular}{|c|c|}
\hline \multicolumn{2}{|c|}{$\begin{array}{c}\text { LOCATION FACTOR } \\
\text { CALCULATED }\end{array}$} \\
\hline MUNICIPIO & $\mathrm{N}^{\circ}$ CÁLCULOS \\
\hline CASTELLÓN & 117 \\
\hline VALENCIA & 505 \\
\hline ALICANTE & 45 \\
\hline TOTAL & 667 \\
\hline
\end{tabular}

\begin{tabular}{|l|c|c|c|}
\hline \multicolumn{4}{|c|}{ USERS VALUATION } \\
\hline & Utilidad & Calidad & $\begin{array}{c}\text { Ahorro } \\
\text { tiempo }\end{array}$ \\
\hline statistical mode & $\mathbf{5 , 0 0}$ & $\mathbf{5 , 0 0}$ & $\mathbf{5 , 0 0}$ \\
\hline statistical median & $\mathbf{5 , 0 0}$ & $\mathbf{5 , 0 0}$ & $\mathbf{5 , 0 0}$ \\
\hline
\end{tabular}


Acknowledgements,

References

Ahearn, M., \& El-Osta, H. (2006). The Impact of Coupled and Decoupled Government Subsidies on Off-Farm Labor Participation of U.S. Farm Operators. American J. of Agricultural Economics, 88(2), 393-408.

Awasthi, M. (2012). Conceptualizing a Multivariate Land Valuation Model. Indian Institute of Management, Seed Money Project Report (SM-181), Lucknow.

Awasthi, M. (2014). Socioeconomic determinants of farmland value in India. Land Use Policy, 39, 78-83.

Barnard, A. (2000). History and theory in anthropology. Cambridge University Press.

Bastian, C., McLeod, D., Germino, M., Reiners, W., \& Blasko, B. (2002).

Environmental amenities and agricultural land values: a hedonic model using geographic information systems data. Ecological Economics, 40, 337-349.

Borchers, A., Ifft, J., \& Kuethe, T. (2014). Linking the Price of Agricultural Land to Use Values and Amenities. American Journal of Agricultural Economics, 96(5), $1307-1320$.

Bouras, C., Filopoulos, A., Kokkinos, V., Michalopoulos, S., Papadopoulos, D., \& Tsel, G. (2014). Policy recommendations for public administrators on free and open source software usage. Telematics and Informatics, 31(2), 237-252.

Burt, O. (1986). Econometric Modeling of the Capitalization Formula for Farmland Prices. American journal of agricultural economics, 68(1), 10-26.

Caballer, V. (2012). Valoraciones de suelo rural. En Manual de Valoraciones Urbanísticas (págs. 25-88). Valencia: Tirant Lo Blanch. 
Cervelló Royo, R. (2008). Tesis Doctoral: Evolución del mercado inmobiliario en centros urbanos. Efectos de la política de intervención pública.

Chicoine, D. (1981). Farmland values at the urban fringe: an analysis of sale prices. Land economics, 353-362.

Cloquell Ballester, V., Cloquell Ballester, V., Santamarina Siurana, M., \& Monterde Díaz, R. (2007). Localización Industrial e Impacto Ambiental (V-553-2007 ed.). Valencia: Editorial de la UPV.

Colwell, P., \& Munneke, H. (1997). The Structure of Urban Land Prices. Journal of Urban Economics, 41(3), 321-336.

Delbecq, B., Kuethe, T., \& Borchers, A. (2014). Identifying the Extent of the Urban Fringe and Its Impact on Agricultural Land Values. LAND ECONOMICS, 90, $587-600$.

Elad, R., Clifton, I., \& Epperson, J. (1994). Hedonic Estimation Applied to the farmland market in Georgia. Journal of Agricultural and Applied Economics, 26(0), 351366.

Faíña, J., \& López-Rodríguez, J. (2006). Renta per cápita, potencial de mercado y proximidad: el caso de España. Papeles de Economía Española, 107, 268.

Featherstone, A. (2003). What's Wrong with Our Models of Agricultural Land Values?: Agricultural Land Values, Government Payments, and Production . American Journal of Agricultural Economics, 744-752.

Freeman, A. (1974). On Estimating Air Pollution Control Benefits from Land Value Studies . Journal of Environmental, Economics and Mangement, 1(May), 74-83.

Ganning, J., Coffin, S., McCall, B., \& Carson, K. (2014). Goals, Challenges, and Capacity of Regional Data Portals in the. Journal of Urban Technology, 125139. 
Geoghegan, J., Wainger, L., \& Bockstael, N. (1997). Spatial landscape indices in a hedonic framework: an ecological economics analysis using GIS. Ecological Economics, 23, 251-264.

Goodwin, B., Mishra, A., \& Ortalo-Magné, F. (2003). What's Wrong with Our Models of Agricultural Land Values? American J. of Agricultural Economics, 85(3), 744-752.

Hormigo, J. (2006). La evolución de los factores de localización de actividades. Minor thesis. Recuperado el 17 de junio de 2015, de http://hdl.handle.net/2099.1/3308

Huang, H., Miller, G., Sherrick, B., \& Gómez, M. (2006). Factors Influencing Illinois Farmland Values. American Journal of Agricultural Economics, 88(2), 458-470.

Hushak, L., \& Sadr, K. (1979). Spatial Model of Land Market Behavior. American Journal of, 61, 697-701.

Hussain, A., Munn, I., Brashier, J., Jones, W., \& Henderson, J. (2013). Capitalization of Hunting Lease Income into Northern Mississippi Forestland Values. Land Economics, 89(1), 137-153.

Idrizi, B., Zhaku, S., Izeiroski, S., \& Kabashi, I. (2014). Defining methodology for selecting most appropriate GIS software. Survey Review, 46(338), 383-389.

Kennedy, G., Dai, M., Henning, S., \& Vandeveer, L. (1996). A GIS-based approach for including topographic and locational attributes in the hedonic analysis of rural land values. En A. J. Econ. (Ed.)., 78, pág. 1419.

Livanisi, G., Moss, C., Breneman, V., \& Nehri, R. (2006). Urban sprawl and farmland prices. American Journal of Agricultural Economics, 88(4), 915-929.

Ma, S., \& Swinton, S. (2011). Valuation of ecosystem services from rural landscapes using agricultural. Ecological Economics, 70, 1649-1659. 
Mishra, A., \& Goodwin, B. (1996). Farm Income Variability and the Supply of OffFarm Labor. American Agricultural Economics Association, 79(3), 880-887.

Mora-Navarro, G. (2013). Tesis Doctoral: Diseño y desarrollo de un modelo de datos dinámico con software libre para la delimitación gráica de las propiedades en España. Universitat Politècnica de València.

Palmquist , R., \& Danielson, L. (1989). A Hedonic Study of the Effects of Erosion Control and Drainage on Farmland Values. American Journal of Agricultural Economics, 71, 55-62.

Plantinga, A., \& Miller, D. (2001). Agricultural Land Values and the Value of Rights to Future Land Development. Land Economics, 77(1), 56-57.

Plantinga, A., Lubowski, R., \& Stavins, R. (2002). The effects of potential land development on agricultural land prices. Journal of Urban Economics, 52, 561581.

Polaski, S., Lewis, D., Platinga, A., \& Nelson, E. (2014). Implementing the optimal provision of ecosystem services. Proceedings of the National Academy of Sciences, 111(17), 6248-6253.

Ramón, M. (1976). Valor actual del modelo de Von Thünen y dos comprobaciones empiricas. Revista de geografia, 10(1), 11-33.

Resch, B., \& Zimmer, B. (2013). User Experience Design in Professional Map-Based Geo-Portals. ISPRS International Journal of Geo-Information. Multidisciplinary Digital Publishing Institute.

Roka, F., \& Palmquist, R. (1997). Examining the Use of National Databases in a Hedonic Analysis of Regional Farmland Values. American Journal of Agricultural Economics, 79(5), 1651-1656. 
Rosen, S. (1974). Hedonic Prices and Implicit Markets: Product Differentiation in Pure Competition. The journal of political economy, 34-55.

Sarrab, M., \& Rehman, O. (2014). Empirical study of open source software selection for adoption, based on software quality characteristics. Advances in Engineering Software, 69(March), 1-11.

Shi, Y., Phipps, T., \& Colyer, D. (1997). Agricultural land values under urbanizing influences. LAND ECONOMICS, 73(1), 90-100.

Van Oosterom, P., Stoter, J., Quak, W., \& Zlatanova, S. (2002). The balance between geometry and topology. Advances in Spatial Data Handling, 209-224.

Vandeveer, L., Kennedy, G., \& Henning, S. (1998). Geographie Information Systems Procedures for Conducting Rural Land Market Research. Review of Agricultural Economics, 20(2), 448-461.

Velilla, J. (2014). PFC: Cálculo de coeficientes para valoración de parcelas según su localización, y publicación de resultados mediante servicios IDE y un cliente ligero.

Velilla, J., Mora-Navarro, G., Marqués-Pérez , I., Femenia-Ribera, C., \& Pérez-Salas, J. (2016). Geovaloración: Desarrollo de un geoportal con software libre para el cálculo del factor de localización en la valoración de parcelas catastrales rústicas en la Comunidad Valenciana. TopCart. Congreso Internacional de Geomática y Ciencias de la Tierra, 13 (171), págs. 27-35. Toledo.

Vitaliano, D., \& Hill, C. (1994). Agricultural districts and farmland prices. Journal of Real Estate Finance and Economics, 8, 213-223.

Zymunt, M., Siejka, M., Ślusarski, M., Siejka, Z., Piech, I., \& Bacior, S. (2014). Database inconsistency errors correction, on example of LPIS databases in Poland. Survey Review, 47(343), 256-264. 